Reticulocytosis may cause a false positive direct AHG test result. ${ }^{18}$ This occurs when the AHG reagent contains antitransferrin which binds to the transferrin found normally on the surface of reticulocytes. Since our positive direct AHG test result was obtained with several reagents, used in different laboratories, this did not appear to be a valid explanation in our case. Furthermore, reticulocyte fractions gave weaker results with AHG than did the spherocyte-rich fractions.

Both Pirofsky ${ }^{2}$ and Brodeur ${ }^{19}$ have suggested that red cell antigenicity might be altered by mechanical damage, resulting in an autoimmune reaction to modified cells. In our case, mechanical fragmentation was not seen so that this explanation is again improbable.

Drug-induced haemolysis would not seem likely in our case because small doses of drugs were used, and antibody testing was not dependent on the presence of drugs in the test system. One irrefutable proof of an autoimmune pathogenesis would be if the haemolysis continued longer than the lifespan of all the transfused blood cells. On this criterion, many previously recorded cases cannot be explained on an autoimmune basis, and delayed haemolytic transfusion reaction is a more likely explanation. In our case haematological recovery was conspicuous 28 days after transfusion, and complete within 43 days, except for the persistence of low titre antibody. Only two previous short reports have suggested isoimmunity as a cause for this syndrome, ${ }^{20}{ }^{21}$ and mechanical red cell fragmentation was present in one of these. Our case clearly shows that isoantibody formation alone can produce marked haemolysis after cardiac surgery and emphasises the careful transfusion management which is required in these cases.
We acknowledge the secretarial help of Mrs Axler and Miss Angold, and the technical expertise of Mr Pat Gribbond. We thank Dr J E Fay, department of medicine, Queen's University, for permission to study this patient.

\section{References}

${ }^{1}$ Marsh, G W, and Lewis, S M, Seminars in Haematology, 1969, 6, 133.

2 Pirofsky, B, et al, New England fournal of Medicine, 1965, 272, 235.

${ }^{3}$ Issitt, P D, Applied Blood Group Serology, Oxnard. California, Spectra Biologicals, 1970.

4 Kaplan, M H, and Dermot Frengley, J, American fournal of Cardiology, 1969, 24, 459 .

5 Hess, E V, et al, fournal of Clinical Investigation, 1964, 43, 886.

${ }^{6}$ Zitnan, D, and Bosmansky, K, Acta Rheumatica Scandinavica, 1966, 12, 267.

${ }^{7}$ Carol, E, et al, Lancet, 1971, 1, 777.

8 Gerber, P, et al, Lancet, 1969, 1, 593.

${ }^{9}$ Perham, T G, et al, British fournal of Haematology, 1971, 20, 307.

10 Lang, D J, Archiv für die gesamte Virus-forschung, 1972, 37, 365.

11 Kwan Park, S, Lancet, 1971, 1, 53.

12 Franklin, A J, Archives of Disease in Childhood, 1972, 47, 474.

${ }_{13}$ Zuelzer, W W, et al, Transfusion (Philadelphia), 1966, 6, 438.

14 Hoffbrand, A F, and Lewis, S M, Haematology, p. 233. London, Heinemann, 1972.

15 Cameron, G L, and Staveley, J M, Nature, 1957, 179, 147.

${ }^{16}$ Morgan, W T, et al, British fournal of Experime:ntal Pathology, 1944, 55, 5.

17 Freisleben, E, et al, Vox Sanguinis, 1961, 6, 304.

$18 \mathrm{Jandl}, \mathrm{J}$ H, Fournal of Laboratory and Clinical Medicine, 1960, 55, 663.

19 Brodeur, M T H, et al, Circulation, 1965, 32, 570.

20 Westring, D W, Annals of Internal Medicine, 1966, 65, 203.

${ }^{21}$ Morse, E E, et al, in 19th Annual Meeting of American Association Blood Banks. Los Angeles, 1966.

\title{
Use of prazosin in management of hypertension in patients with chronic renal failure and in renal transplant recipients
}

\author{
J R CURTIS, F J A BATEMAN
}

British Medical fournal, 1975, 4, 432-434

\section{Summary}

Prazosin was used in combination with other antihypertensive drugs in the successful management of hypertension in seven patients with chronic renal failure and six renal transplant recipients, also with chronic renal failure. The addition of small doses of prazosin (mean $3 \mathrm{mg} /$ day) to the antihypertensive regimen produced significant falls in systolic and diastolic blood pressures in both the lying and standing positions. The standing blood pressures were significantly lower than the lying blood pressures during prazosin treatment. Neither the mean blood urea concentrations nor the mean plasma creatinine concentrations changed significantly during prazosin administration. Chromium-51 edetic acid clearances did not change significantly during prazosin treatment in the seven patients in whom it was measured.

\footnotetext{
Department of Medicine, Charing Cross Hospital Medical School, London

J R CURTIS, MD, FRCP, senior lecturer and consultant nephrologist

Pfizer Limited, Sandwich, Kent

F J A BATEMAN, MB, BS, medical director
}

Severe symptomatic postural hypotension occurred in one patient a week after starting prazosin $3 \mathrm{mg} / \mathrm{day}$. This hypotensive episode was associated with a transient and reversible deterioration in renal function. Another patient developed a rash while on prazosin but it was probably related to propranolol rather than prazosin. Prazosin is thus an effective antihypertensive drug in patients with chronic renal failure, and it may be used with a variety of other drugs. It should be used cautiously, however, since patients with chronic renal failure may respond to small doses, and significant postural falls in blood pressure may result. There was no evidence that the use of prazosin resulted in progressive deterioration in the residual renal function of the patients with chronic renal failure.

\section{Introduction}

Prazosin is a relatively new antihypertensive drug, which has been used in patients with normal renal function. ${ }^{1}$ We report here its use in combination with other antihypertensive drugs in the management of hypertension in patients with chronic renal failure. Preliminary observations suggested that patients with chronic renal failure might respond to relatively small doses of the drug and that use of the drug, at least in combination with others, was associated with significant postural falls in blood pressure and a slight fall in the ${ }^{51} \mathrm{Cr}$-edetic acid clearance. ${ }^{2}$ 


\section{Methods}

Twelve patients with chronic renal failure, five of whom were renal transplant recipients, were studied. One patient was studied twice. All patients gave their informed consent to the use of prazosin. Details of the patients are shown in table I.

TABLE I-Age, sex, diagnosis, and initial renal function of patients studied

\begin{tabular}{|c|c|c|c|}
\hline Case no & Age and sex & Diagnosis & $\begin{array}{l}{ }^{51} \mathrm{Cr} \text {-edetic acid } \\
\text { clearance } \\
\quad(\mathrm{ml} / \mathrm{min})\end{array}$ \\
\hline $\begin{array}{l}1 \\
2 \\
3 \\
4 \\
5\end{array}$ & $\begin{array}{l}53 \mathrm{M} \\
55 \mathrm{M} \\
56 \mathrm{~F} \\
65 \mathrm{M} \\
64 \mathrm{M}\end{array}$ & $\begin{array}{l}\text { Nephrosclerosis } \\
\text { Chronic glomerulonephritis } \\
\text { Nephrosclerosis } \\
\text { Chronic obstructive nephropathy } \\
\text { Renal artery stenosis, } \\
\text { nephrosclerosis }\end{array}$ & $\begin{array}{c}34 \\
309^{*} \\
57 \\
65 \cdot 0 \dagger \\
186^{*}\end{array}$ \\
\hline $\begin{array}{l}6 \\
7\end{array}$ & $\begin{array}{l}67 \mathrm{M} \\
73 \mathrm{M}\end{array}$ & $\begin{array}{l}\text { Polyarteritis nodosa } \\
\text { Renal artery stenosis, } \\
\text { nephrosclerosis }\end{array}$ & $\begin{array}{c}239 * \\
38\end{array}$ \\
\hline $\begin{array}{r}8 \\
9 \\
10 \\
11 \\
12 \\
12\end{array}$ & $\begin{array}{l}28 \mathrm{M} \\
28 \mathrm{M} \\
36 \mathrm{~F} \\
53 \mathrm{M} \\
23 \mathrm{M} \\
23 \mathrm{M}\end{array}$ & $\begin{array}{l}\text { Renal transplant recipient } \\
\text { Renal transplant recipient } \\
\text { Renal transplant recipient } \\
\text { Renal transplant recipient } \\
\text { Renal transplant recipient } \\
\text { Renal transplant recipient }\end{array}$ & $\begin{array}{l}54 \\
47 \\
28 \\
40 \\
33 \\
23\end{array}$ \\
\hline
\end{tabular}

*Plasma creatinine $\mu \mathrm{mol} / 1(1 \mu \mathrm{mol} / 1 \approx 0.0113 \mathrm{mg} / 100 \mathrm{ml})$. Endogenous creatinine clearance $\mathrm{ml} / \mathrm{min}$.

All patients were on a variety of other antihypertensive drugs, including one or more of the following: propranolol, clonidine, chlorothiazide, frusemide, and methyldopa. These drugs were continued through the control and prazosin treatment periods. The renal transplant recipients were also on routine immunosuppression with azathioprine and prednisone. The blood pressure was recorded with a random zero sphygmomanometer (Hawksley, England) in the lying and standing positions. The means of at least two measurements of blood pressure, blood urea, and plasma creatinine concentrations during the month before starting prazosin were used as the control observations in the seven patients with chronic renal failure who were not transplanted. In the case of the five transplanted patients control observations taking the mean of at least two measurements of blood pressure, blood urea, and plasma creatinine were made over two to three days since most of these patients presented as hypertensive emergencies; indeed, in three patients parenteral treatment with clonidine and hydrallazine was initially necessary to keep the diastolic blood pressure below $120 \mathrm{~mm} \mathrm{Hg}$.

After the control observations prazosin was added to the antihypertensive regimens of these patients, initially in a dose of $1 \mathrm{mg}$ three times a day. One patient developed severe symptomatic postural hypotension after one week on this dose, so that subsequent patients were started on a dose of $1 \mathrm{mg}$ twice a day. The dose was increased at intervals of two to four weeks, depending on the response of the blood pressure. The mean dose of prazosin was $3 \mathrm{mg} /$ day (range 2-6 $\mathrm{mg}$ ), and the mean period of prazosin treatment was 10 weeks (range 4-18 weeks). Patients were seen during prazosin treatment every one to four weeks, when lying and standing blood pressures were recorded with a random zero sphygmomanometer, and blood was taken for estimation of blood urea, plasma creatinine, liver function, and blood sugar. In seven of the patients ${ }^{51} \mathrm{Cr}$-edetic acid clearances were measured before and during prazosin treatment. The mean blood pressure and blood urea and plasma creatinine concentrations during prazosin treatment were based on an average of four separate observations (range 2-13).

\section{Results}

Table II shows the mean systolic and diastolic blood pressures in each patient before and during prazosin treatment and drug dosages for each patient.

The standing systolic blood pressure fell significantly during prazosin administration when compared with the control $(T=1$; critical value of $T$ for $\mathrm{N}=13$ is 10 at level of significance of 0.01 for a two-tailed test using Wilcoxon's matched-pairs signed-ranks test). Lying systolic and lying and standing diastolic blood pressures fell significantly during prazosin administration when compared with the control period ( $\mathrm{T}=0$; critical value of $\mathrm{T}$ for $\mathrm{N}=13$ is 10 at level of significance of 0.01 for a two-tailed test using Wilcoxon's matchedpairs signed-ranks test).

There was no significant difference between the lying and standing systolic blood pressures during the control period ( $T=17.5$; critical value of $\mathrm{T}$ for $\mathrm{N}=12$ is 14 at level of significance of 0.05 for a twotailed test using Wilcoxon's matched-pairs signed-ranks test). There was no significant difference between the lying and standing diastolic blood pressures during the control period $(T=20$; critical value of $T$ for $\mathrm{N}=9$ is 6 at level of significance of 0.05 for a two-tailed test using Wilcoxon's matched-pairs signed-ranks test). There was, however, a significant fall in the standing systolic blood pressure when compared with the lying systolic blood pressure during the period of prazosin adininistration $(T=0$; critical value of $T$ for $N=13$ is 10 at level of significance of 0.01 for a two-tailed test using Wilcoxon's matchedpairs signed-ranks test). There was also a significant fall in the standing diastolic blood pressure when compared with the lying diastolic blood pressure during the period of prazosin administration $(T=1.5$; critical value of $\mathrm{T}$ for $\mathrm{N}=12$ is 7 at level of significance of 0.01 for a two-tailed test using Wilcoxon's matched-pairs signed-ranks test).

The average blood pressure for all patients before prazosin treatment was $194 / 120 \mathrm{~mm} \mathrm{Hg}$ lying, and $187 / 119 \mathrm{~mm} \mathrm{Hg}$ standing. The average blood pressure for all patients during prazosin treatment was $167 / 103$ $\mathrm{mm} \mathrm{Hg}$ lying and $149 / 96 \mathrm{~mm} \mathrm{Hg}$ standing.

Table III shows the mean blood urea and plasma creatinine concentrations in the control periods and during prazosin treatment. There was no significant difference between the blood urea concentra-

TABLE II-Blood pressures $(\mathrm{mm} \mathrm{Hg}$ ) before and during prazosin treatment

\begin{tabular}{|c|c|c|c|c|c|c|c|}
\hline \multirow{2}{*}{ Case no. } & \multirow{2}{*}{ Position } & \multicolumn{2}{|c|}{ Control } & \multicolumn{2}{|c|}{ During prazosin } & \multirow{2}{*}{$\underset{(\mathrm{mg} / \mathrm{d})}{\operatorname{Prazosin}}$} & \multirow{2}{*}{ Other drugs } \\
\hline & & Systolic & Diastolic & Systolic & Diastolic & & \\
\hline 1 & $\begin{array}{l}\text { Lying } \\
\text { Standing }\end{array}$ & $\begin{array}{l}185 \\
195\end{array}$ & $\begin{array}{l}110 \\
105\end{array}$ & $\begin{array}{l}178 \\
153\end{array}$ & $\begin{array}{l}95 \\
92\end{array}$ & 2 & Propranolol (160 mg tds) \\
\hline 2 & $\begin{array}{l}\text { Lying } \\
\text { Standing }\end{array}$ & $\begin{array}{l}190 \\
168\end{array}$ & $\begin{array}{l}120 \\
120\end{array}$ & $\begin{array}{l}149 \\
148\end{array}$ & 97 & 4 & $\begin{array}{l}\text { Clonidine (0.15 mg gds), propranolol ( } 240 \mathrm{mg} \text { gds), } \\
\text { chlorothiazide }(500 \mathrm{mg} / \mathrm{d})\end{array}$ \\
\hline 3 & Lying & 225 & 137 & 155 & 95 & 3 & Clonidine (0.15 mg gds), propranolol ( $320 \mathrm{mg} \mathrm{gds}$ ), \\
\hline 4 & $\begin{array}{l}\text { Standing } \\
\text { Lying }\end{array}$ & $\begin{array}{l}210 \\
200\end{array}$ & $\begin{array}{l}109 \\
113\end{array}$ & $\begin{array}{l}150 \\
159\end{array}$ & $\begin{array}{r}95 \\
110\end{array}$ & $\begin{array}{l}3 \\
3\end{array}$ & $\begin{array}{l}\text { methyldopa ( } 750 \mathrm{mg} \text { gds }) \\
\text { Propranolol (20 mg gds) }\end{array}$ \\
\hline & Standing & 170 & 120 & 134 & 96 & & al i. \\
\hline 5 & Lying & 178 & $\begin{array}{l}118 \\
115\end{array}$ & $\begin{array}{l}167 \\
162\end{array}$ & $\begin{array}{r}102 \\
95\end{array}$ & 3 & Clonidine $(0.2 \mathrm{mg} \mathrm{tds})$, chlorothiazide $(500 \mathrm{mg} / \mathrm{d})$ \\
\hline 6 & $\begin{array}{l}\text { Lying } \\
\text { Standing }\end{array}$ & 220 & $\begin{array}{l}122 \\
132\end{array}$ & $\begin{array}{l}177 \\
144\end{array}$ & $\begin{array}{r}110 \\
92\end{array}$ & 3 & $\begin{array}{l}\text { Propranolol ( } 240 \mathrm{mg} \text { gds}) \text {, clonidine }(0.15 \mathrm{mg} \text { tds }), \\
\text { frusemide }(40 \mathrm{mg} / \mathrm{d})\end{array}$ \\
\hline 7 & $\begin{array}{l}\text { Lying } \\
\text { Standing }\end{array}$ & $\begin{array}{l}235 \\
237\end{array}$ & 122 & $\begin{array}{l}223 \\
206\end{array}$ & $\begin{array}{l}116 \\
118\end{array}$ & 6 & Propranolol ( $80 \mathrm{mg}$ tds $)$, chlorothiazide $(500 \mathrm{mg} / \mathrm{d})$ \\
\hline 8 & $\begin{array}{l}\text { Lying } \\
\text { Ltanding }\end{array}$ & $\begin{array}{l}182 \\
166\end{array}$ & 122 & $\begin{array}{l}161 \\
138\end{array}$ & $\begin{array}{r}113 \\
97\end{array}$ & 2 & Methyldopa (250 mg tds), propranolol (10 tds), \\
\hline 9.. & $\begin{array}{l}\text { Standing } \\
\text { Lying. }\end{array}$ & 174 & $116^{*}$ & 142 & 89 & 2 & Propranolol (10 mg bd), azathioprine (100 $\mathrm{mg} / \mathrm{d})$, \\
\hline 10 & $\begin{array}{l}\text { Standing } \\
\text { Lying }\end{array}$ & $\begin{array}{l}170 \\
169\end{array}$ & $\begin{array}{l}116 \\
122\end{array}$ & $\begin{array}{l}122 \\
165\end{array}$ & $\begin{array}{r}85 \\
110\end{array}$ & 6 & $\begin{array}{l}\text { prednisone }(10 \mathrm{mg} / \mathrm{d}) \\
\text { Frusemide }(40 \mathrm{mg} / \mathrm{d}) \text {, azathioprine }(150 \mathrm{mg} / \mathrm{d})\end{array}$ \\
\hline & Standing & 159 & 118 & 160 & 108 & & prednisone $(15 \mathrm{mg} / \mathrm{d})$ \\
\hline 11 & Lying & $\begin{array}{l}203 \\
199\end{array}$ & $\begin{array}{l}105 \\
117\end{array}$ & $\begin{array}{l}196 \\
168\end{array}$ & $\begin{array}{l}104 \\
100\end{array}$ & 3 & $\begin{array}{l}\text { Clonidine }(0.15 \mathrm{mg} \mathrm{tds}) \text {, chlorothiazide }(500 \mathrm{mg} / \mathrm{d}) \text {, } \\
\text { azathioprine }(150 \mathrm{mg} / \mathrm{d}) \text {, prednisone }(8 \mathrm{mg} / \mathrm{d})\end{array}$ \\
\hline 12 & $\begin{array}{l}\text { Lying } \\
\text { Standing }\end{array}$ & $\begin{array}{l}167 \\
148\end{array}$ & $\begin{array}{l}105^{*} \\
114\end{array}$ & $\begin{array}{l}148 \\
128\end{array}$ & $\begin{array}{r}102 \\
92\end{array}$ & 3 & $\begin{array}{l}\text { Methyldopa }(500 \mathrm{mg} \text { bd), propranolol }(80 \mathrm{mg} \text { bd), } \\
\text { frusemide }(40 \mathrm{mg} / \mathrm{d}), \text { azathioprine }(100 \mathrm{mg} / \mathrm{d}) \\
\text { prednisone }(10 \mathrm{mg} / \mathrm{d})\end{array}$ \\
\hline 12 & $\begin{array}{l}\text { Lying } \\
\text { Standing }\end{array}$ & $\begin{array}{l}200 \\
200\end{array}$ & $\begin{array}{l}150^{*} \\
150\end{array}$ & $\begin{array}{l}155 \\
126\end{array}$ & $\begin{array}{r}108 \\
93\end{array}$ & 3 & $\begin{array}{l}\text { Methyldopa ( } 250 \mathrm{mg} \text { bd), propranolol }(80 \mathrm{mg} \mathrm{tds}) \\
\text { frusemide }(80 \mathrm{mg} \text { tds }) \text {, azathioprine }(100 \mathrm{mg} / \mathrm{d}), \\
\text { preanisone }(10 \mathrm{mg} / \mathrm{d}) .\end{array}$ \\
\hline
\end{tabular}


tions in the control and prazosin periods $(T=28.5$; critical value of $\mathrm{T}$ for $\mathrm{N}=12$ is 14 at level of significance of 0.05 for a two-tailed test using Wilcoxon's matched-pairs signed-ranks test). There was no significant difference between the plasma creatinine concentrations in the control and prazosin periods $(T=23.5$; critical value of $T$ for $\mathrm{N}=10$ is 8 at level of significance of 0.05 for a two-tailed test using Wilcoxon's matched-pairs signed-ranks test).

TABLE III-Mean blood urea and plasma creatinine concentrations during control and prazosin periods

\begin{tabular}{|c|c|c|c|c|}
\hline \multirow[t]{2}{*}{ Case no } & \multicolumn{2}{|c|}{$\underset{(\mathrm{mmol} / \mathrm{l})}{\text { Mean blood urea }}$} & \multicolumn{2}{|c|}{$\begin{array}{c}\text { Mean plasma creatinine } \\
(\mu \mathrm{mol} / 1)\end{array}$} \\
\hline & Control & During prazosin & Control & During prazosin \\
\hline $\begin{array}{r}1 \\
2 \\
3 \\
4 \\
5 \\
6 \\
7 \\
8 \\
9 \\
10 \\
11 \\
12 \\
12\end{array}$ & $\begin{array}{r}13.3 \\
13.8 \\
5.6 \\
7.6 \\
8.6 \\
15.8 \\
5.3 \\
7.8 \\
6.0 \\
5.2 \\
12.5 \\
9.3 \\
7.0\end{array}$ & $\begin{array}{r}13.8 \\
15.1 \\
5.6 \\
6.8 \\
8.8 \\
14.6 \\
6.1 \\
6.0 \\
7.8 \\
8.8 \\
12.6 \\
7.5 \\
9.6\end{array}$ & $\begin{array}{l}186 \\
309 \\
124 \\
141 \\
186 \\
239 \\
186 \\
124 \\
133 \\
141 \\
168 \\
195 \\
177\end{array}$ & $\begin{array}{r}186 \\
318 \\
88 \\
115 \\
168 \\
256 \\
168 \\
124 \\
168 \\
168 \\
186 \\
195 \\
203\end{array}$ \\
\hline
\end{tabular}

Conversion: $S I$ to traditional units-Urea: $1 \mathrm{mmol} / 1 \approx 6 \mathrm{mg} / 100 \mathrm{ml}$. Creatinine: $1 \mu \mathrm{mol} / \mathrm{l} \approx .0113 \mathrm{mg} / 100 \mathrm{ml}$

Table IV shows the ${ }^{51} \mathrm{Cr}$-edetic acid clearance values during the control and prazosin periods in the seven patients in whom it was measured. There was no significant difference between the clearance results in the control period and during prazosin treatment $(T=11$; critical value of $\mathrm{T}$ for $\mathrm{N}=7$ is 2 at level of significance of 0.05 for a two-tailed test using Wilcoxon's matched-pairs signed-ranks test).

TABLE IV- ${ }^{51} \mathrm{Cr}$-edetic acid clearance values during control and prazosin periods in seven patients

\begin{tabular}{lll|c|c|c|c|c|c|c}
\hline & \multicolumn{2}{c|}{ Case no: } & 1 & 7 & $8^{*}$ & $9^{*}$ & 10 & $11^{*}$ & 12 \\
\hline Control $\ldots$ & $\ldots$ & $\ldots$ & 34 & 38 & 40 & 47 & 23 & 28 & 24 \\
During prazosin & $\ldots$ & $\ldots$ & 41 & 31 & 27 & 38 & 22 & 24 & 92 \\
\hline
\end{tabular}

* Suffered possible mild rejection episode before or during prazosin administration.

\section{SIDE EFFECTS}

One patient (case 2) developed an unusual erythema nodosumlike eruption after receiving prazosin for about five weeks. This patient was also taking clonidine, chlorothiazide, and propranolol so that it is difficult to be sure of the cause. There was no improvement after the cessation, first of chlorothiazide treatment and then of prazosin, but slow improvement followed the cessation of propranolol treatment. It seems unlikely therefore that prazosin was responsible. A chest $x$-ray examination showed no hilar lymphadenopathy, and a serum antinuclear factor test gave a negative result.

Another patient (case 9) developed severe symptomatic postural hypotension about a week after being on prazosin $1 \mathrm{mg}$ three times a day together with propranolol $10 \mathrm{mg}$ three times a day. This necessitated a reduction in dose and there was a transient reversible deterioration in renal function, the plasma creatinine rising from 168 to 239 $\mu \mathrm{mol} / 1(1.9-2.7 \mathrm{mg} / 100 \mathrm{ml})$, and then returning to its previous level over three to four days. This was at the time attributed to, and treated as, a mild rejection episode, but it is more likely to have been due to the severe postural hypotension, the standing systolic blood pressure being between $80-90 \mathrm{~mm} \mathrm{Hg}$ for about 24 hours.

Standard liver function tests, including estimations of serum bilirubin, plasma alkaline phosphatase, serum transaminase, and random blood sugar concentrations, were normal in all patients during prazosin administration.

\section{Discussion}

Our results showed that prazosin was useful in combination with other antihypertensive drugs in controlling severe hypertension in patients with chronic renal failure. Prazosin must be used with caution in such patients, however, because they may respond to relatively small doses. The manufacturers suggest an initial dose of $2 \mathrm{mg}$ three times a day, increasing gradually to a daily maximum of $20 \mathrm{mg}$. We found that the mean daily effective dose was $3 \mathrm{mg}$, with a range of $2-6 \mathrm{mg} /$ day. One patient developed severe postural hypotension while on a dose of $1 \mathrm{mg}$ three times a day, and subsequently all patients with chronic renal failure were started on $1 \mathrm{mg}$ twice a day. Studies in normal subjects (Pfizer's research department, unpublished data) have shown that only $3-4 \%$ of a given dose of prazosin is excreted over 24 hours in the urine and that this fraction is largely excreted as a metabolite. It therefore seems unlikely that the increased sensitivity to prazosin in patients with renal failure is due to accumulation of the drug.

The manufacturers have also suggested that prazosin has little tendency to cause orthostatic hypotension. This may be true when it is used alone, but when used in combination with the other antihypertensive drugs in this study a significant postural fall in blood pressure followed the addition of prazosin.

There was no evidence of further deterioration of renal function during treatment with prazosin in the 12 patients with chronic renal failure as judged by the blood urea and plasma creatinine concentrations, with the exception of the patient who developed severe postural hypotension, which was associated with a transient and reversible rise in the plasma creatinine concentration.

It is difficult to evaluate the significance of the ${ }^{51} \mathrm{Cr}$-edetic acid results, firstly because the numbers studied were small and, secondly, because five of the seven patients were renal transplant recipients, and three of these transplanted patients were considered to have had mild rejection episodes some time before they were treated with prazosin. Consequently, their renal function might not have been in a steady state. Nevertheless, no significant difference between the ${ }^{51} \mathrm{Cr}$-edetic acid clearances in control periods and during prazosin treatment could be shown in this limited study.

Side effects were few and limited to one patient with pronounced postural hypotension. It is doubtful whether a rash in another patient could be attributed to prazosin. There were no cases of sudden collapse or loss of consciousness occurring within 30 to 90 minutes of the initial dose of prazosin, as has been reported to the Committee on Safety of Medicines.

We thank Mr Grant Williams, consultant urologist and transplant surgeon, Charing Cross Hospital, for allowing us to study patients under his care, Dr R J Jewkes, consultant in nuclear medicine, Charing Cross Hospital, for the ${ }^{51} \mathrm{Cr}$-edetic acid clearance measurements, and Pfizer Limited for providing a Hawksley Random Zero Sphygmomanometer and for supplies of prazosin. Blood urea, blood sugar, liver function, and plasma creatinine were measured in the department of chemical pathology, Charing Cross Hospital, through the courtesy of Professor J H Wilkinson.

\section{References}

1 Stokes, G S, and Weber, M A, British Medical fournal, 1974, 2, 298. 2 Curtis, J R, British Medical fournal, 1974, 3, 742. 